\title{
Influence of sociodemographic characteristics on different dimensions of household food insecurity in Montevideo, Uruguay
}

\author{
Máximo Rossi ${ }^{1, *}$, Zuleika Ferre ${ }^{1}$, María Rosa Curutchet ${ }^{2}$, Ana Giménez ${ }^{3}$ and \\ Gastón $\mathrm{Ares}^{3}$ \\ 'Departamento de Economía, Facultad de Ciencias Sociales, Universidad de la República, Constituyente 1502, \\ CP 11200 , Montevideo, Uruguay: ${ }^{2}$ Observatorio de Seguridad Alimentaria y Nutricional, Instituto Nacional de \\ Alimentación, Montevideo, Uruguay: ${ }^{3}$ Sensometrics \& Consumer Science, Instituto Polo Tecnológico de Pando, \\ Facultad de Química, Universidad de la República, Pando, Canelones, Uruguay
}

Submitted 30 March 2016: Final revision received 3 August 2016: Accepted 9 August 2016: First published online 17 October 2016

\begin{abstract}
Objective: To determine the factor structure of the Latin American \& Caribbean Household Food Security Scale (ELCSA) and to study the influence of sociodemographic characteristics on each of the identified dimensions in Montevideo, Uruguay.

Design: Cross-sectional survey with a representative sample of urban households. Household food insecurity was measured using the ELCSA. The percentage of respondents who gave affirmative responses for each of the items of the ELCSA was determined. Exploratory factor analysis was carried out to determine the ELCSA's factor structure. A probit model was used to determine the impact of some individual and household sociodemographic characteristics on the identified dimensions of food insecurity.

Setting: Metropolitan area centred on Montevideo, the capital city of Uruguay, April-September 2014.

Subjects: Adults aged between 18 and 93 years ( $n$ 742).

Results: The percentage of affirmative responses to the items of the ELCSA ranged from 4.4 to $31.7 \%$. Two factors were identified in the exploratory factor analysis performed on data from households without children under 18 years old, whereas three factors were identified for households with children. The identified factors were associated with different severity levels of food insecurity. Likelihood of experiencing different levels of food insecurity was affected by individual characteristics of the respondent as well as characteristics of the household.

Conclusions: The influence of sociodemographic variables varied among the ELCSA dimensions. Household income had the largest influence on all dimensions, which indicates a strong relationship between income and food insecurity.
\end{abstract}

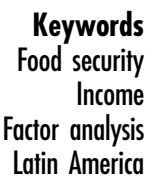

Keywords

Income

Latin America
Food security occurs when 'all people, at all times have physical and economic access to sufficient, safe and nutritious food that meets their dietary needs and food preferences for an active and healthy life ${ }^{,(1)}$. Food security is a multidimensional concept that involves four hierarchical dimensions: (i) physical availability of food; (ii) economic and physical access to food; (iii) food utilization; and (iv) stability of the previous dimensions over time ${ }^{(2)}$.

When individuals do not have access to sufficient food in terms of both quantity and quality, food insecurity is experienced. Food insecurity has been classified into three main severity levels ${ }^{(3)}$. Food insecurity usually starts by mild insecurity, which is characterized by uncertainty or fear about running out of food in the future or eating foods that are less preferred or less healthful ${ }^{(4)}$. Moderate food insecurity has been associated with restriction of both the quality and quantity of food ${ }^{(3)}$. Finally, the most severe form of food insecurity is hunger (the uneasy or painful sensation caused by insufficient food consumption) ${ }^{(2)}$, which is met when people do not have access to enough food to meet their basic needs. Food insecurity usually affects the adults in the household first as children are usually protected by their mothers. When the severity of food insecurity increases it is no longer possible to protect them and food insecurity reaches the children of the household ${ }^{(5)}$. 
The effects of food insecurity are diverse and range from increased risk of malnutrition or disease and negative psychological consequences to a decrease in productivity and economic performance ${ }^{(6-12)}$. For this reason, the benefits of strategies to cope with food insecurity go beyond individuals and also extend to the whole society.

Measuring household food insecurity provides an estimate of its underlying causes and contributes to the development of intervention strategies and policies to alleviate its consequences ${ }^{(13)}$. Given the multidimensional nature of food insecurity, a variety of methods have been used for its measurement ${ }^{(14)}$. For many years, food insecurity has been measured based on economic indicators of food production and food availability, as well as dietary intake and anthropometric measures ${ }^{(15)}$. However, these methods are deemed insufficient to measure all the aspects related to food insecurity ${ }^{(16)}$. For this reason, scales for measuring food insecurity as it is experienced by individuals have been developed ${ }^{(3,15,17,18)}$, following the pioneering work of Radimer et al. ${ }^{(17)}$, Briefel et al. ${ }^{(19)}$ and Wehler et $a l^{(20)}$.

The Latin American \& Caribbean Household Food Security Scale (ELCSA) was developed by modifying the US Household Food Security Survey Module (HFSSM) and translating the terms into Spanish ${ }^{(21)}$. This scale measures the perception of different aspects of food insecurity, as reported by a member of the household, and includes questions related to worries about running out of food and lack of access to food in sufficient quantity or quality, due to lack of monetary or other restrictions ${ }^{(22)}$. The operationalization of ELCSA depends on whether or not children are present in the household, which is a common feature of several food security scales due to the specific nutritional needs of children ${ }^{(16)}$. This scale has been used in several Latin American countries, including Bolivia, Brazil, Colombia, Ecuador, Mexico and Uruguay ${ }^{(21-25)}$. All of the previous studies have considered ELCSA as one-dimensional and have not considered the different dimensions of food insecurity included in the scale. However, several studies have identified different dimensions in food insecurity scales, which account for different severity in food insecurity ${ }^{(26)}$. In the specific case of ELCSA, only one study has been found assessing the factor structure of the scale using factor analysis ${ }^{(27)}$. In that study, conducted with Colombian pregnant adolescents from low-income households, three factors were identified, which accounted for $75 \%$ of the variance. The first factor comprised items related to food quality and lack of food, whereas items related to concern and anxiety about access to food were related to the second factor, and items related to lack of food for the children of the household and no socially acceptable means to acquire food were related to the third factor. However, further research on this is still necessary to understand the dimensions involved in food insecurity, as evaluated by the ELCSA ${ }^{(28)}$.
Effective interventions aimed at reducing food insecurity depend on accurate targeting of the vulnerable population ${ }^{(27)}$. Understanding the relationship between food insecurity and sociodemographic variables underlying food insecurity can contribute to the development of preventive measures that alleviate the consequences of food insecurity ${ }^{(15)}$. Food insecurity occurs for multiple reasons, with socio-economic factors being the most relevant as they can limit access to food ${ }^{(13,27)}$. Households with children, living under poverty conditions, located far from urban areas and headed by single mothers or ethnic minorities have been reported to have the highest risk of household food insecurity ${ }^{(29-34)}$.

The present work deals with the evaluation of food insecurity in Uruguay, a country in south-east South America with a population of approximately 3.3 million people. Between 2006 and 2013 the percentage of households under poverty conditions decreased markedly from 24.2 to $17.8 \%$ due to economic growth and social policies ${ }^{(35)}$. Although this reduction in poverty is expected to cause a reduction in food insecurity, economic growth on its own does not address aspects of food insecurity related to the quality of food consumed ${ }^{(2)}$. This makes it necessary to develop strategies that reduce poverty in conjunction with policies to ensure food security ${ }^{(36)}$. However, Uruguay has not yet adopted national programmes to assess household food insecurity that would allow the government to develop specific strategies aimed at improving access to and utilization of food for the most vulnerable segments of the population.

In this context, the aim of the present work was to determine the factor structure of the ELCSA and to study the influence of sociodemographic characteristics on each of the identified dimensions in Montevideo, Uruguay.

\section{Methods}

\section{Data collection}

The present study was part of a cross-sectional survey designed to assess dietary patterns in a representative sample of urban households from the metropolitan area centred on Montevideo, the capital city of Uruguay. According to the 2011 national census this area comprises 1319108 inhabitants and 520538 private households ${ }^{(37)}$.

A three-stage stratified random sampling method was considered. The first stage consisted of the random selection of 305 primary census areas, stratified by geographical location and socio-economic level. The second stage comprised a random selection of 1220 households from the primary census tracts. The number of households per tract was selected considering the number of occupied private households. Lastly, an adult (at least 18 years old) was randomly selected from each household.

Information letters were sent to the households. Then, trained interviewers went directly to the households to 
establish face-to-face contact with the selected adult from each household (up to five attempts on different days and at different times were considered). From the initial sample of 1220 households, complete data were obtained from 742 (this implies a response rate above $60 \%$, which is considered appropriate for this type of study), which comprised the final sample. This sample size enabled the estimation of population proportions with a precision of $\pm 3.5 \%$ for a confidence level of $95 \%$.

The survey was implemented by a group of fifty interviewers, most of whom were social science students with previous experience in population surveys. The interviewers received training on the content of the survey prior to its administration. Data from all surveys were checked by a supervisor and $20 \%$ of the households were contacted by telephone to check that they had answered the survey.

All participants gave verbal consent. Data collection was carried out between April and September 2014.

\section{Housebold food insecurity}

Household food insecurity was measured using the $\operatorname{ELCSA}^{(21)}$. This scale comprises eight items for households without children under 18 years of age and fifteen questions for households with children (Table 1). Respondents had to answer yes or no to each of the items. A score of 1 was given for each positive answer.

Table 1 Items of the Latin American \& Caribbean Household Food Security Scale (ELCSA), back-translated from Spanish. Items 9-15 are considered only for households with children under 18 years of age

During the last 3 months, due to lack of money or other Item resources...

1 Were you worried that your household would run out of food?

2 Did your household run out of food?

3 Did your household lack a healthy diet?

4 Did you or any adult in your household have to consume only a few types of food?

5 Did you or any adult in your household not eat breakfast, lunch or dinner?

6 Did you or any adult in your household eat less than you thought you should?

$7 \quad$ Did you or any adult in your household feel hungry but couldn't eat?

8 Did you or any adult in your household eat only once a day or go without eating for a whole day?

9 Did any children under 18 years of age in your household not receive a healthy diet?

10 Did any children under 18 years of age in your household have to consume only a few types of food?

11 Did any children under 18 years of age in your household not eat breakfast, lunch or dinner?

12 Did any children under 18 years of age in your household eat less than you thought necessary?

13 Did you have to serve less food to any children under 18 years of age in your household?

14 Did any children under 18 years of age feel hungry but couldn't eat in your household?

15 Did any children under 18 years of age eat only once a day or go without eating for a whole day in your household?

\section{Sociodemographic data}

The following sociodemographic information was collected from each participant: gender, age, years of education of the respondent, number of adults in the household, number of children under 18 years in the household, if the house was owned by the participant's family, number of rooms in the household, if the household had a place to cook, whether they were beneficiaries of food programmes and possession of a set of goods (stove, refrigerator, freezer, cable connection, washing machine, dryer, dishwasher, microwave, Internet, heating, computer, car, motorcycle).

\section{Data analysis}

\section{Factor analysis}

Exploratory factor analysis was carried out to determine the factor structure of the ELCSA. Factors were extracted using principal component analysis and orthogonally rotated with the varimax rotation. This type of factor analysis is the most widely used in several disciplines and is the default option in many statistical packages ${ }^{(38)}$. The number of factors was selected using parallel analysis ${ }^{(39)}$. Items with loadings above 0.40 were considered significant $^{(40)}$.

Influence of sociodemographic characteristics on the dimensions of the food insecurity scale

A probit model was used to determine the impact of some individual and household sociodemographic characteristics on the dimensions of the food insecurity scale.

The models were estimated using individual characteristics (gender, age and years of education), three variables representing household characteristics (number of adults in the household, number of rooms per capita, kitchen) and a set of variables that captured household income (home ownership, if the home is covered by a government assistance programme and an index of deprivation). Two models were estimated: one for households with children under 18 years and the other for households without children. Table 2 provides a description of the variables used in the models and their descriptive statistics.

\section{Results}

\section{Descriptive statistics}

The percentage of participants who provided only negative responses to the items of the ELCSA, which indicates food security, was 69.5 (95\% CI 64.5, 74.2)\% for households without children under 18 years old and 49.9 (95\% CI $43 \cdot 7,56 \cdot 2) \%$ for households with children. Considering these results, the percentage of people experiencing food security in Montevideo can be estimated as 60.8 (95\% CI $56 \cdot 8,64 \cdot 7) \%$. 
Table 2 Description of the independent variables included in the probit model relating the dimensions of food insecurity and sociodemographic variables in a representative sample of urban households from the metropolitan area centred on Montevideo, Uruguay, April-September 2014

\begin{tabular}{llrr}
\hline Variable & Description & Mean & SD \\
\hline Gender & 1 if female & 0.58 & 0.49 \\
Age & Age of the respondent & 48.88 & 18.28 \\
Years_educ & Years of education of the respondent & 10.42 & 4.65 \\
Numb_adults & Number of adults in the household & 2.13 & 0.99 \\
Numb_child & Number of children under 18 years of age in the household & 0.77 & 1.17 \\
Homeowner & 1 if the household is owner of the house & 0.59 & 0.49 \\
Rooms_per_capita & Number of rooms per capita & 0.77 & 0.39 \\
Cooking_place & 1 if the household has a place to cook & 0.95 & 0.21 \\
Food_programmes & 1 if the household receives a food assistance programme & 0.11 & 0.31 \\
Privation & Index of deprivation* & 0.25 & 0.20 \\
\hline
\end{tabular}

*The index reflects the household's level of deprivation. It is based considering the possession of a set of goods (stove, refrigerator, freezer, cable connection, washing machine, dryer, dishwasher, microwave, Internet, heating, computer, car, motorcycle). The indicator takes the value 1 if the household has a total lack of goods considered and 0 in the case of possessing all. For details of the methodology of the deprivation index, see Borooah ${ }^{(65)}$.

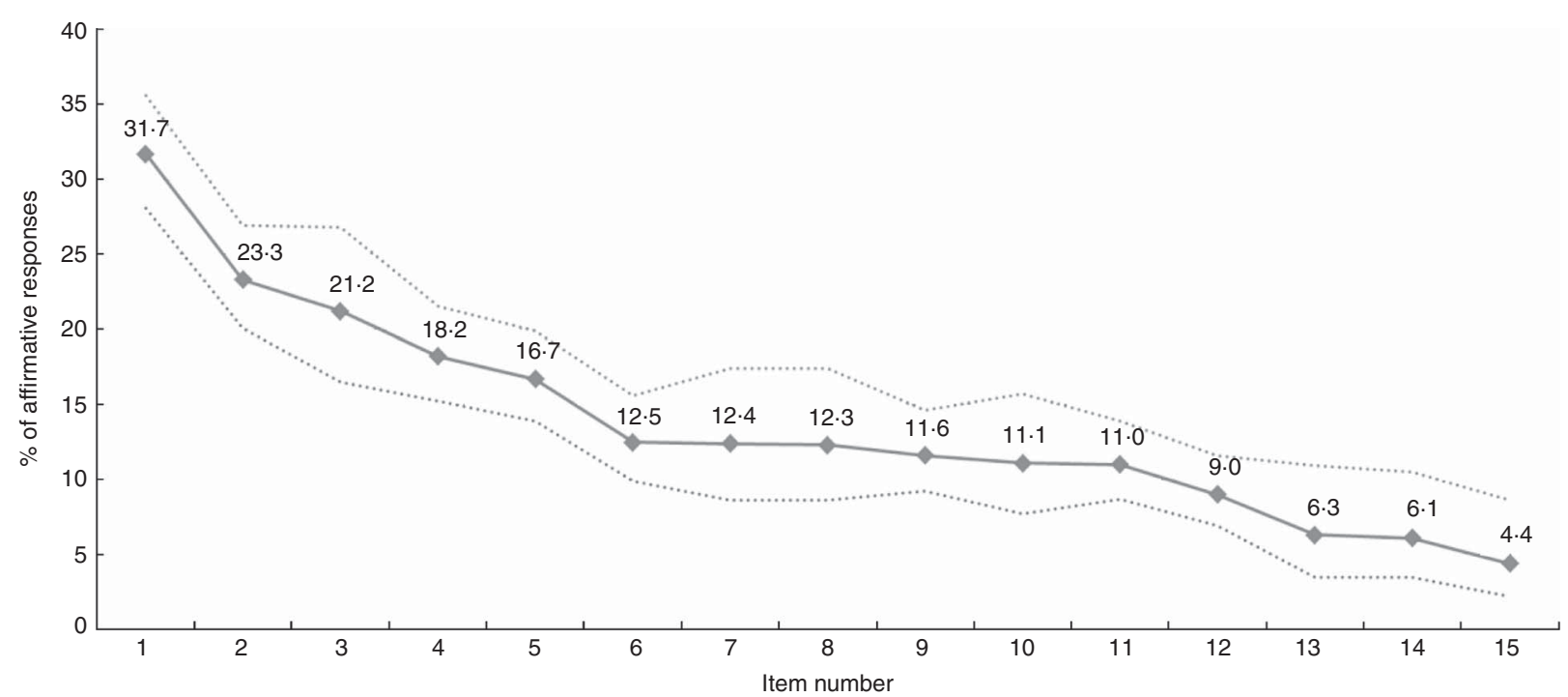

Fig. 1 Percentage of affirmative responses to each item of the Latin American \& Caribbean Household Food Security Scale (ELCSA) in a representative sample of urban households from the metropolitan area centred on Montevideo, Uruguay, April-September 2014. Dotted lines represent the $95 \%$ confidence interval and the full wording of the numbered items is shown in Table 1

Figure 1 shows the percentage of affirmative responses to each of the items of the ELCSA. As expected, items related to less severe aspects of food insecurity (e.g. item 1, worried about running out of food) showed a higher percentage of affirmative responses than items associated with severe food insecurity (e.g. item 14, a child under 18 years of age felt hungry but couldn't eat). Besides, for the same severity, child-related items tended to have a lower percentage of affirmative responses than adult-related items. For example, the percentage of affirmative responses for the item related to feeling hungry but being unable to eat was $12.4 \%$ for adults and $6.1 \%$ for children under 18 years of age (Fig. 1).

\section{Factor analysis}

Exploratory factor analysis was used to determine the factor structure of the ELCSA. Parallel analysis indicated that the optimal solution contained two factors for households without children less than 18 years of age. As shown in Table 3, Factor 1 was correlated to items related to a lack of food in the household that indicate moderate/severe food insecurity. Factor 2 was correlated to items related to worry about running out of food and items related to lack of a wholesome and healthy diet, which are associated with mild food insecurity.

In the case of households with children under 18 years of age, three factors were identified through a clear demarcation in parallel analysis (Table 4). The items included in Factor 1 for these households were the same as those in Factor 1 for households with no children (cf. Tables 3 and 4), being related to terms associated with a lack of food for the household. Factor 3 was correlated to the items that denote mild food insecurity (i.e. worry about running out of foods and balanced diet). Factor 2 was related to the items associated with a lack of food for the 
Table 3 Factor loadings of the items of the Latin American \& Caribbean Household Food Security Scale (ELCSA) for households without children under 18 years of age in a representative sample of urban households from the metropolitan area centred on Montevideo, Uruguay, April-September 2014

\begin{tabular}{lcr}
\hline Item & Factor 1 & Factor 2 \\
\hline 1 & 0.18 & $\mathbf{0 . 5 2}$ \\
2 & $\mathbf{0 . 7 2}$ & 0.14 \\
3 & 0.07 & $\mathbf{0 . 7 8}$ \\
4 & -0.04 & $\mathbf{0 . 8 3}$ \\
5 & $\mathbf{0 . 8 5}$ & -0.04 \\
6 & $\mathbf{0 . 5 9}$ & 0.31 \\
7 & $\mathbf{0 . 7 5}$ & 0.05 \\
8 & $\mathbf{0 . 8 0}$ & -0.13 \\
\% variance explained & 38 & 24 \\
\hline
\end{tabular}

Factor loadings greater than 0.40 are highlighted in bold.

Table 4 Factor loadings of the items of the Latin American \& Caribbean Household Food Security Scale (ELCSA) for households with children under 18 years of age in a representative sample of urban households from the metropolitan area centred on Montevideo, Uruguay, April-September 2014

\begin{tabular}{lccr}
\hline Item & Factor 1 & Factor 2 & Factor 3 \\
\hline 1 & 0.34 & -0.07 & $\mathbf{0 . 4 5}$ \\
2 & $\mathbf{0 . 7 3}$ & -0.01 & 0.15 \\
3 & 0.26 & -0.03 & $\mathbf{0 . 6 5}$ \\
4 & -0.02 & 0.01 & $\mathbf{0 . 8 4}$ \\
5 & $\mathbf{0 . 7 8}$ & 0.14 & -0.04 \\
6 & $\mathbf{0 . 6 5}$ & -0.05 & 0.29 \\
7 & $\mathbf{0 . 7 2}$ & -0.04 & 0.11 \\
8 & $\mathbf{0 . 7 8}$ & 0.1 & -0.17 \\
9 & 0.05 & $\mathbf{0 . 4 4}$ & 0.39 \\
10 & 0.02 & 0.23 & $\mathbf{0 . 7 0}$ \\
11 & -0.07 & $\mathbf{0 . 8 8}$ & 0.05 \\
12 & 0.29 & $\mathbf{0 . 5 2}$ & 0.12 \\
13 & 0.26 & $\mathbf{0 . 4 2}$ & 0.24 \\
14 & 0.14 & $\mathbf{0 . 4 8}$ & 0.03 \\
15 & 0.07 & $\mathbf{0 . 8 0}$ & -0.08 \\
$\%$ variance explained & 25 & 19 & 18 \\
\hline
\end{tabular}

Factor loadings greater than 0.40 are highlighted in bold.

children, indicating severe food insecurity. It is interesting to note that although the item related to a lack of healthy diet in the household (item 3, cf. Table 1) was correlated to terms related to diet quality, the item denoting a lack of healthy food for the children (item 9, cf. Table 1) was correlated with items that indicate lack of food for the children.

\section{Influence of sociodemographic characteristics on the different dimensions of food insecurity}

A probit model was estimated in order to determine the impact of some individual and household characteristics (described in Table 2) on each of the dimensions of food insecurity.

Results for moderate/severe (Factor 1) and mild food insecurity (Factor 2) for households with no children under 18 years of age are presented in Table 5, whereas estimations for moderate (Factor 1), severe (Factor 2) and mild food insecurity (Factor 3) for households with children under 18 years old are presented in Table 6.

For households composed exclusively of adults, the estimations for Factor 1, corresponding to moderate/ severe food insecurity, showed that the probability of experiencing a situation of moderate/severe food insecurity declined with the age and educational level of the respondent, when the family owned their house and when the household had an appropriate place for cooking (Table 5). Having an appropriate place to cook (kitchen) reduced the likelihood of moderate/severe food insecurity by 23 percentage points.

The likelihood of experiencing moderate/severe food insecurity increased when the household received food assistance through special programmes and as the level of deprivation increased (Table 5). The variables that attempted to capture household income were the most important to determine moderate/severe household food insecurity. In particular, owning the house decreased the risk of being in a situation of moderate/severe food insecurity by 7 percentage points, whereas deprivation increased this situation by 41 percentage points. Besides, being covered by state programmes, which already shows vulnerability in terms of revenues, increased the probability of moderate/severe food insecurity by 38 percentage points.

In the case of Factor 2, which indicates mild food insecurity, the probability of experiencing mild food insecurity increased slightly when the respondent was female compared with male (by 8 percentage points) and as the level of deprivation increased (by 38 percentage points). On the other hand, mild food insecurity was reduced with the years of education of the respondent and if the household had an appropriate cooking place.

In the case of households with children under 18 years of age, the probability of severe, moderate and mild food insecurity was reduced with the level of education of the respondent (by 2, 5 and 3 percentage points, respectively). Meanwhile, the chance of moderate and severe insecurity increased with the number of children in the household and with the level of deprivation. The number of children in the household increased the likelihood of severe and moderate food insecurity by between 6 and 7 percentage points, whereas it did not significantly affect likelihood of experiencing mild food insecurity.

Mild, moderate and severe food insecurity was each markedly related to the level of deprivation, being the variable with the largest influence. As shown in Table 6, the likelihood of experiencing any level of food insecurity increased by between 31 and 63 percentage points with deprivation.

\section{Discussion}

Food insecurity in Montevideo was estimated as 39\%, which indicates that food insecurity is still an important 
Table 5 Coefficients and marginal effects of probit model estimation for households without children under 18 years in a representative sample of urban households from the metropolitan area centred on Montevideo, Uruguay, April-September 2014

\begin{tabular}{|c|c|c|c|c|}
\hline \multirow[b]{2}{*}{ Dependent variable } & \multicolumn{2}{|c|}{$\begin{array}{c}\text { Factor } 1 \\
\text { (moderate/severe food insecurity) }\end{array}$} & \multicolumn{2}{|c|}{$\begin{array}{c}\text { Factor } 2 \\
\text { (mild food insecurity) }\end{array}$} \\
\hline & Coefficient & Marginal effect & Coefficient & Marginal effect \\
\hline Gender (female) & 0.108 & & $0.255^{\star}$ & 0.083 \\
\hline SE & 0.178 & & -0.149 & -0.049 \\
\hline Age & $-0.011^{\star \star}$ & -0.002 & -0.005 & \\
\hline SE & 0.005 & 0.001 & 0.004 & \\
\hline Years_educ & $-0.043^{*}$ & -0.008 & $-0.038^{\star *}$ & -0.013 \\
\hline $\mathrm{SE}$ & 0.024 & 0.004 & 0.019 & -0.006 \\
\hline Numb_adults & 0.072 & & -0.122 & \\
\hline $\mathrm{SE}$ & $0 \cdot 101$ & & 0.088 & \\
\hline Rooms_per_capita & 0.305 & & -0.297 & \\
\hline SE & 0.223 & & 0.206 & \\
\hline Cooking_place & $-0.843^{\star \star}$ & -0.234 & $-0.817^{\star}$ & -0.309 \\
\hline SE & 0.424 & 0.154 & 0.463 & -0.181 \\
\hline Homeowner & $-0.345^{\star}$ & -0.067 & -0.090 & \\
\hline SE & 0.198 & 0.041 & 0.168 & \\
\hline Food_programmes & $1 \cdot 242^{\star \star *}$ & 0.384 & - & - \\
\hline $\mathrm{SE}^{-1}$ & 0.426 & 0.166 & - & - \\
\hline Privation & $2 \cdot 219^{\star \star \star}$ & 0.407 & $1 \cdot 165^{\star \star}$ & 0.381 \\
\hline SE & 0.584 & 0.115 & 0.485 & -0.159 \\
\hline Constant & -0.171 & & 1.058 & \\
\hline SE & 0.803 & & 0.659 & \\
\hline Observations $(n)$ & 418 & & 406 & \\
\hline
\end{tabular}

${ }^{* \star \star} P<0.01,{ }^{* \star} P<0.05,{ }^{\star} P<0.1$.

Table 6 Coefficients and marginal effects of probit model estimation for households with children under 18 years in a representative sample of urban households from the metropolitan area centred on Montevideo, Uruguay, April-September 2014

\begin{tabular}{|c|c|c|c|c|c|c|}
\hline \multirow[b]{2}{*}{ Dependent variable } & \multicolumn{2}{|c|}{$\begin{array}{c}\text { Factor } 1 \\
\text { (moderate food insecurity) }\end{array}$} & \multicolumn{2}{|c|}{$\begin{array}{c}\text { Factor } 2 \\
\text { (severe food insecurity) }\end{array}$} & \multicolumn{2}{|c|}{$\begin{array}{c}\text { Factor } 3 \\
\text { (mild food insecurity) }\end{array}$} \\
\hline & Coefficient & Marginal effect & Coefficient & Marginal effect & Coefficient & Marginal effect \\
\hline Gender (female) & 0.041 & & 0.128 & & 0.116 & \\
\hline SE & 0.196 & & 0.205 & & 0.176 & \\
\hline Age & -0.009 & & 0.004 & & 0.000 & \\
\hline SE & 0.009 & & 0.008 & & 0.008 & \\
\hline Years_educ & $-0 \cdot 171^{\star \star \star}$ & -0.050 & $-0.092^{\star \star}$ & -0.019 & $-0.075^{\star \star \star}$ & -0.030 \\
\hline SE & 0.039 & 0.009 & 0.039 & 0.007 & 0.023 & 0.009 \\
\hline Numb_adults & 0.032 & & 0.131 & & 0.081 & \\
\hline SE & 0.102 & & 0.109 & & 0.089 & \\
\hline Numb_child & $0.255^{\star *}$ & 0.074 & $0 \cdot 277^{\star \star \star}$ & 0.057 & 0.131 & \\
\hline $\mathrm{SE}$ & 0.103 & 0.032 & 0.098 & 0.023 & 0.099 & \\
\hline Homeowner & -0.186 & & -0.301 & & -0.082 & \\
\hline SE & 0.196 & & 0.212 & & 0.182 & \\
\hline Rooms_per_capita & 0.700 & & 0.288 & & -0.427 & \\
\hline $\mathrm{SE}-1-$ & 0.578 & & 0.602 & & 0.560 & \\
\hline Cooking_place & -0.051 & & -0.148 & & $-0 \cdot 100$ & \\
\hline SE & 0.366 & & 0.354 & & 0.413 & \\
\hline Food_programmes & 0.074 & & 0.089 & & 0.193 & \\
\hline $\mathrm{SE}$ & 0.299 & & 0.249 & & 0.254 & \\
\hline Privation & $1.646^{\star \star \star}$ & 0.478 & $1.500^{\star *}$ & 0.308 & $1.573^{\star \star}$ & 0.628 \\
\hline SE & 0.620 & 0.187 & 0.676 & 0.148 & 0.670 & 0.267 \\
\hline Constant & 0.164 & & -1.469 & & 0.253 & \\
\hline SE & 0.996 & & 1.026 & & 0.809 & \\
\hline Observations $(n)$ & 295 & & 297 & & 296 & \\
\hline
\end{tabular}

${ }^{* * \star} P<0.01,{ }^{* \star} P<0.05,{ }^{\star} P<0.1$.

problem. As expected, the prevalence of food insecurity was similar to that reported previously in Uruguay ${ }^{(41)}$ and other Latin American countries, such as Brazil ${ }^{(42)}$, Colombia $^{(28,43)}$, Venezuela ${ }^{(44)}$ and Argentina ${ }^{(45)}$, but much higher than that reported in developed countries such as
Canada, France, New Zealand or the USA ${ }^{(31,34,46-49)}$. Although the number of undernourished people in Latin America and the Caribbean more than halved between 1990 and 2014, meeting the Millennium Development Goal and the World Food Summit, hunger still affects more 
than 34 million people in Latin America ${ }^{(50)}$. Differences between countries in the prevalence of food insecurity have been explained by the influence of socioeconomic factors, public policies and social assistance programmes ${ }^{(50,51)}$

Food insecurity was significantly higher in households with children than in those without. Having children in the household increased the prevalence of food insecurity by $28 \%$ compared with households without children, in agreement with other studies conducted in Canada and the USA ${ }^{(49)}$. The higher prevalence of food insecurity in households with children in Montevideo can be explained by the high prevalence of poverty among children. In 2014 the percentage of children living under poverty conditions in Uruguay was $20 \%$, while poverty prevalence among adults aged 65 years or over was only $2 \%{ }^{(52)}$.

Affirmative responses to the individual items of the ELCSA decreased with the items' severity (Fig. 1), as expected $^{(21)}$. The percentages of affirmative responses were similar to those reported five years ago by PérezEscamilla et $a l{ }^{(25)}$. Although Uruguay lacks routine national monitoring of food insecurity, results from the present work suggest that household food insecurity has not decreased since 2006. This result was not expected since the Uruguayan economy has experienced a steady growth in the last 10 years, which has been accompanied by social policies aimed at reducing poverty ${ }^{(35)}$. In this sense, it is important to stress that hunger is not only the result of a lack of food but is also related to inequalities in the mechanisms of food distribution and lack of access to better living conditions ${ }^{(53)}$. Rivera et al. have reported that improvement in income did not lead to an improvement in the quality and variety of foods ${ }^{(54)}$. Therefore, public policies aimed at reducing food insecurity should improve income distribution in the country and also provide additional support to vulnerable families. An increase in social support and nutritional education in vulnerable households can contribute to reducing food insecurity ${ }^{(55)}$.

For the same severity, the percentage of affirmative responses was higher for items related to adults than for items related to children, in agreement with the assumption that children are usually protected within the household and that they are usually the last to experience food insecurity ${ }^{(55)}$. In this sense, it is interesting to highlight that the item denoting lack of healthy food for the children was correlated with the factor which indicates moderate food insecurity (Table 4).

The factor structure of the ELCSA was assessed using exploratory factor analysis. The optimum solution identified two independent factors in the ELCSA when it was applied to households without children under 18 years old, and three independent factors when it was applied to households with children. As shown in Tables 3 and 4, the factors grouped the ELCSA items into different severity levels: mild and moderate in households composed only of adults; and mild, moderate and severe in households with children. These results are in agreement other studies conducted in Latin American countries when using different scales to measure household food insecurity ${ }^{(44,56-58)}$. Therefore, the complex construct of food insecurity seems to be multidimensional, being composed of different independent dimensions related to its severity. The consideration of these separate dimensions may enable a better understanding of the determinants of food insecurity in different populations.

In the present work, a probit model was used to model the influence of sociodemographic characteristics of the respondents and the households on the identified dimensions of food insecurity (Table 2). Although the influence of sociodemographic variables varied among the dimensions of the ELCSA, the deprivation index, which was a proxy variable to measure household income, was the strongest predictor of all of the dimensions of food insecurity (Tables 5 and 6). Research in different countries has shown that food insecurity is strongly negatively associated with household income ${ }^{(34,48,51,59,60)}$. This result is consistent with the definition of food insecurity ${ }^{(1)}$, as insufficient income is expected to prevent individuals from getting enough food to meet their physiological and psychological needs. According to Sarlio-Lähteenkorva and Laherlma ${ }^{(59)}$, past economic disadvantage also positively contributes to food insecurity, particularly mild food insecurity, as it increases worries and fears about running out of food. This result stresses the importance of implementing social programmes aimed at increasing the availability of money for food purchase in vulnerable households. In this sense, it is interesting to highlight that the results showed severe and moderate food insecurity was higher in those households that received social food programmes (Table 5), which indicates that these programmes are being adequately targeted at the most vulnerable population.

Regarding the individual characteristics of the respondents, educational level was the strongest predictor of household food insecurity, in agreement with several studies which show that the most vulnerable people to food insecurity usually have the least number of years of education $^{(34,42,51,61)}$. The negative association between education and food insecurity can be explained by considering that lower educational levels are usually negatively associated with income and social status.

Regarding gender, it significantly increased influenced responses to the mild food insecurity dimension of the ELCSA in households without children only (Table 5). The greater vulnerability of women to food insecurity has been reported by several authors, who have attributed it to family composition and the fact that women tend to deprive themselves to protect their children ${ }^{(34,42,48,49,62,63)}$. However, Hadley et al. ${ }^{(64)}$ have argued the existence of gender bias in the questions included in the food insecurity scales. According to these authors, differences between males and females can be explained considering 
differences in tolerance to stress. This explanation seems plausible as females are in charge of food preparation in most households. In this sense, results from the present work sum up to this hypothesis by showing that gender differences were observed only for the dimension of food insecurity related to worrying about running out of food. Further research on the influence of personal characteristics on responses to household food insecurity scales may contribute to develop guidelines on how to select respondents in surveys to accurately estimate the prevalence of food insecurity.

\section{Conclusions}

The present study showed that food insecurity affects a considerable proportion of the population in Montevideo, Uruguay. It should be remembered that this work is restricted to an urban population and the results in a rural population could be quite different. The percentages of affirmative responses to the items of the ELCSA were similar to those reported in the literature five years ago, which suggests that the reduction of poverty experienced in the same period did not lead to a decrease in food insecurity. A special outcome is that the differences by gender were observed only in the dimension of food insecurity related to worrying about running out of food. All results stress the need to perform national routine studies aimed at measuring the prevalence of household food insecurity and identifying its causes. Besides, public policies based on comprehensive visions of the food system seem necessary to improve access to adequate quantity and quality of food.

Two independent dimensions were identified in the ELCSA, which suggests that the influence of sociodemographic variables on each separate dimension may provide a more accurate understanding of the determinants of the different severity levels of food insecurity. Household income had the largest influence on responses to all of the dimensions, which indicates a strong relationship between income and food insecurity. Further research should be conducted to improve our understanding of the variables that can reduce vulnerability to food insecurity in the Uruguayan context and to identify the most effective public policies that can help to cope with this problem.

\section{Acknowledgements}

Financial support: The authors are grateful to Espacio Interdisciplinario (Universidad de la República, Uruguay) for financial support. The funder had no role in the design, analysis or writing of this article. Conflict of interest: None. Authorship: All authors contributed to the development of the research and wrote the paper. M.R., Z.F. and G.A. analysed the data. Ethics of human subject participation:
This study was conducted according to the guidelines laid down in the Declaration of Helsinki and all procedures involving human subjects/patients were approved by the Ethics Committee of Facultad de Química, Universidad de la República (Uruguay). Verbal informed consent was obtained from all participants. Verbal consent was witnessed and formally recorded.

\section{References}

1. Food and Agriculture Organization of the United Nations (1996) Cumbre Mundial sobre la Alimentación. Declaración de Roma sobre la Seguridad Alimentaria Mundial y Plan de Acción. Rome: FAO; available at http://www.fao. org/wfs/index_es.htm

2. Food and Agriculture Organization of the United Nations (2008) An Introduction to Basic Concepts of Food Security. Rome: FAO; available at http://www.fao.org/docrep/013/ al936e/al936e00.pdf

3. Segall-Corrêa AM, Pérez-Escamilla R, Marin-Léon L et al. (2008) Evaluation of household food insecurity in Brazil: validity assessment in diverse sociocultural settings. In Iniciativa America Latina y Caribe Sin Hambre, Concurso redSAN 2007: Memoria artículos ganadores, pp. 80-101 [J Ortega, editor]. Santiago: Oficina Regional FAO-Chile; available at http://www.bvsde.paho.org/texcom/nutricion/ memredsan_3.pdf

4. Maxwell DG (1996) Measuring food insecurity: the frequency and severity of 'coping strategies'. Food Policy 21, 291-303.

5. Pérez-Escamilla R, Melgar-Quiñonez $\mathrm{H}$, Nord $\mathrm{M}$ et al. (2007) Escala Latinoamericana y Caribeña de Seguridad Alimentaria (ELCSA) (Latinamerican and Caribbean Food Security Scale). Perspectivas en Nutrición Humana (Colombia) Suppl., 117-134.

6. Vozoris NT \& Tarasuk VS (2003) Household food insufficiency is associated with poorer health. J Nutr 133, 120-126.

7. Sullivan AF, Clark S, Pallin DJ et al. (2010) Food security, health, and medication expenditures of emergency department patients. J Emerg Med 38, 524-528.

8. Whitaker RC, Phillips SM \& Orzol SM (2006) Food insecurity and the risks of depression and anxiety in mothers and behavior problems in their preschool-aged children. Pediatrics 118, E859-E868.

9. Weigel MM, Armijos RX, Hall YP et al. (2007) The household food insecurity and health outcomes of US-Mexico border migrant and seasonal farmworkers. J Immigr Minor Health 3, 157-169.

10. Lent MD, Petrovic LE, Swanson JA et al. (2009) Maternal mental health and the persistence of food insecurity in poor rural families. J Health Care Poor Underserved 20, 645-661.

11. Seligman HK, Bindman AB, Vittinghoff E et al. (2007) Food insecurity is associated with diabetes mellitus: results from the National Health Examination and Nutrition Examination Survey (NHANES) 1999-2002. J Gen Intern Med 22, 1018-1023.

12. Seligman HK, Laraia BA \& Kushel MB (2010) Food insecurity is associated with chronic disease among low-income NHANES participants. $J$ Nutr 140, 304-310.

13. Corral L, Winters P \& Gordillo G (2000) Food Insecurity and Vulnerability in Latin America and the Caribbean. Armidale, NSW: University of New England, Graduate School of Agricultural and Resource Economics.

14. Carletto C, Zezza A \& Banerjee R (2013) Towards better measurement of household food security: harmonizing 
indicators and the role of household surveys. Glob Food Sec 2, 30-40.

15. Pérez-Escamilla R \& Segall-Corrêa AM (2008) Food insecurity measurement and indicators. Rev Nutr 21, Suppl., 15S-26S.

16. Marques ES, Reichenheim ME, de Moraes CL et al. (2015) Household food insecurity: a systematic review of the measuring instruments used in epidemiological studies. Public Health Nutr 18, 877-892.

17. Radimer KL, Olson CM \& Campbell CC (1990) Development of indicators to assess hunger. J Nutr 120, 1544-1548.

18. Coates J (2013) Build it back better: deconstructing food security for improved measurement and action. Glob Food $\operatorname{Sec} 2,188-194$.

19. Briefel RR \& Woteki CE (1992) Development of food insufficiency questions for the Third National Health and Nutrition Examination Survey. J Nutr Educ 24, Suppl. 1, 24S-28S.

20. Wehler CA, Scott RI \& Anderson JJ (1992) The community childhood hunger identification project: a model of domestic hunger: demonstration project in Seattle, Washington. J Nutr Educ 24, Suppl. 1, 29S-35S.

21. Comité Científico de la ELCSA (2012) Escala Latinoamericana y Caribeña de Seguridad Alimentaria (ELCSA): Manual de uso y aplicaciones. Rome: FAO.

22. Kaiser LL, Melgar-Quiñonez HR, Lamp CL et al. (2002) Food security and nutritional outcomes of preschool-age Mexican-American children. $J$ Am Diet Assoc 102, 924-929.

23. Melgar-Quiñonez HR, Zubieta AC, MkNelly B et al. (2006) Household food insecurity and daily per capita food expenditure in Bolivia, Burkina Faso and the Philippines. J Nutr 136, issue 5, 1431S-1437S.

24. Pérez-Escamilla R, Segall-Corrêa AM, Kurdian Maranha L et al. (2004) An adapted version of the US Department of Agriculture food insecurity module is a valid tool for assessing household food insecurity in Campinas, Brazil. J Nutr 134, 1923-1928.

25. Pérez-Escamilla R, Parás P, Acosta MJ et al. (2011) Are the Latin American and Caribbean Food Security Scale (ELCSA) items comparable across countries? FASEB J 25, 226-228.

26. Kendall A, Olson CM \& Frongillo EA Jr (1995) Validation of the Radimer/Cornell measures of hunger and food insecurity. J Nutr 125, 2793-2801.

27. Barrett CB (2010) Measuring food insecurity. Science 327, 825-828.

28. Muñoz-Astudillo MN, Martínez JW \& Quintero AR (2010) Validación de la Escala Latinoamericana y Caribeña de Seguridad Alimentaria en gestantes adolescentes. Rev Salud Publica 12, 173-183.

29. Rose D (1999) Economic determinants and dietary consequences of food insecurity in the United States. $J$ Nutr 129, 2 S Suppl., 517S-520S.

30. Langellier BA, Chaparro MP, Sharp M et al. (2014) Trends and determinants of food insecurity among adults in lowincome households in California. J Hunger Environ Nutr 7, 401-413.

31. Nord M, Andrews M \& Carlson S (2008) Housebold Food Security in the United States, 2007. Economic Research Report no. ERR-66. Washington, DC: US Department of Agriculture, Economic Research Service; available at http:// www.ers.usda.gov/Publications/ERR66/

32. Segall-Corrêa AM, Marín-León L, Sampaio MFA, Panigassi G et al. (2007) Insegurança alimentar no Brasil: do desenvolvimento do instrumento de medida aos primeiros resultados nacionais. In Avaliação de Políticas e Programas do MDS: Resultados Vol. I. Segurança Alimentar e Nutricional, pp. 385-407 [Ministério do Desenvolvimento Social e Combate à Fome, editor]. Brasília DF: Ministério do Desenvolvimento Social e Combate à Fome.
33. Consejo Nacional de Evaluación de la Política de Desarrollo Social (2010) Dimensiones de la seguridad alimentaria: Evaluación Estratégica de Nutrición y Abasto. México, DF: CONEVAL

34. Bocquier A, Vieux F, Lioret S et al. (2015) Socio-economic characteristics, living conditions and diet quality are associated with food insecurity in France. Public Health Nutr 18, 2952-2961.

35. Ministerio de Desarrollo Social (2014) Revisión de Indicadores Básicos de Desarrollo Social 2006-2013. Montevideo: MIDES.

36. Stamoulis K \& Zezza A (2003) A Conceptual Framework for National Agricultural, Rural Development, and Food Security Strategies and Policies. ESA Working Paper no. 03-17. Rome: FAO; available at ftp://ftp.fao.org/docrep/fao/ 007/ae050e/ae050e00.pdf

37. Instituto Nacional de Estadística, Uruguay (2011) Viviendas y Población en el País Según Departamento. Censos de Población años 1908, 1963, 1975, 1996, 2004 (Fase 1) y 2011. Montevideo: INE; available at http://www.ine.gub. uy/web/guest/censos-2011

38. Costello AB \& Osborne JW (2005) Best practices in exploratory factor analysis: four recommendations for getting the most from your analysis. Pract Assess Res Eval 10, 7.

39. Glorfeld LW (1995) An improvement on Horn's parallel analysis methodology for selecting the correct number of factors to retain. Educ Psychol Meas 55, 377-393.

40. Hair JF, Anderson RE \& Tatham RL (1987) Multivariate Analysis with Readings, 2nd ed. London: Macmillan Publishing Company.

41. Instituto Nacional de Estadística, Uruguay (2015) Encuesta de Nutrición, Desarrollo Infantil y Salud 2015 (ENDIS). http://www.ine.gub.uy/web/guest/encuesta-nacional-dedesarrollo-infantil-y-salud-endis- (acesssed April 2016).

42. Salles-Costa R, Pereira RA, de Vasconcelllos MTL et al. (2008) Association between socioeconomic factors and food insecurity: a population-based study in the Rio de Janeiro metropolitan area, Brazil. Rev Nutr 21, Suppl., 99S-109S.

43. Álvarez Uribe MC (2010) Caracterización de los hogares de Colombia en Inseguridad Alimentaria según Calidad de Vida. Rev Salud Publica 12, 877-888.

44. Bernal J \& Lorenzana PA (2007) La escala de seguridad alimentaria en hogares aplicada a adolescentes en Caracas: una medida valida y confiable. Agroalimentaria 12, 47-54, 474-481.

45. Rosso M, Wicky A, Nessier M et al. (2015) Inseguridad alimentaria en la ciudad de Santa Fe: percepción de los ciudadanos. Salud Colect 11, 235-245.

46. Coleman-Jensen A, Nord M \& Singh A (2013) Household Food Security in the United States in 2012. Economic Research Report no. ERR-155. Washington, DC: US Department of Agriculture, Economic Research Service; available at http://www.ers.usda.gov/media/1183208/err-155.pdf

47. Office of Nutrition Policy and Promotion, Health Canada (2010) Household Food Insecurity in Canada in 2007-08: Key Statistics and Graphics. Ottawa, ON: Health Canada.

48. Carter KN, Lanumata T, Kruse K et al. (2010) What are the determinants of food insecurity in New Zealand and does this differ for males and females? Aust $N Z J$ Public Health 34, 602-608.

49. Nord M, Hooper MD \& Hopwood H (2008) Household level income-related food insecurity is less prevalent in Canada than in the United States. J Hunger Environ Nutr 3, $17-35$.

50. Food and Agriculture Organization of the United Nations (2015) Panorama de la Inseguridad Alimentaria en América Latina y El Caribe. La región alcanza las metas internacionales del hambre. Rome: FAO. 
51. Interlenghi GS \& Salles-Costa R (2015) Inverse association between social support and household food insecurity in a metropolitan area of Rio de Janeiro, Brazil. Public Health Nutr 18, 2925-2933.

52. Observatorio de Seguridad Alimentaria y Nutricional INDA (2015) Derecho a la Alimentación, Seguridad Alimentaria y Nutricional: Logros y Desafíos de Uruguay. http://obsan-inda.mtss.gub.uy/2016/01/26/derecho-a-laalimentacion-seguridad-alimentaria-y-nutricional-logros-ydesafios-de-uruguay (accessed March 2016).

53. Sen A (1982) Poverty and Famines: An Essay on Entitlements and Deprivation. Oxford: Clarendon Press.

54. Rivera B, Currais L \& Rungo P (2009) Impacto de los programas de transferencia condicionada de renta sobre el estado de salud: el Programa Bolsa Familia de Brasil. Rev Esp Salud Publica 83, 85-97.

55. Kempson K, Keenan DP, Sadani PS et al. (2003) Maintaining food sufficiency: coping strategies identified by limitedresource individuals versus nutrition educators. J Nutr Educ Behav 35, 179-188.

56. Lorenzana PA \& Sanjur D (1999) Abbreviated measures of food sufficiency validly estimate the food security level of poor households: measuring household food security. J Nutr 129, 687-692.

57. Álvarez MC, Estrada A, Montoya EC et al. (2006) Validación de escala de la seguridad alimentaria doméstica en Antioquia, Colombia. Salud Publica Mex 48, 474-481.
58. Gulliford MC, Nunes C \& Rocke B (2006) The 18 Household Food Security Survey items provide valid food security classifications for adults and children in the Caribbean. $B M C$ Public Health 6, 26.

59. Sarlio-Lahteenkorva S \& Lahelma E (2001) Food insecurity is associated with past and present economic disadvantage and body mass index. J Nutr 131, 2880-2884.

60. Tingay RS, Tan CJ, Tan NC et al. (2003) Food insecurity and low income in an English inner city. J Public Health Med 25 , 156-159.

61. Panigassi G, Segall-Corrêa AM, Marin-Léon L et al. (2008) Insegurança alimentar como indicador de iniqüidade: análise de inquérito populacional. Cad Saude Publica $\mathbf{2 4}$, 2376-2384.

62. Hamelin AM, Beaudry M \& Habicht JP (2002) Characterization of household food insecurity in Quebec: food and feelings. Soc Sci Med 54, 119-132.

63. Vizcarra Bordi I (2008) Entre las desigualdades de género: un lugar para las mujeres pobres en la seguridad alimentaria y el combate al hambre. Argumentos (México, DF) 21, 141-173.

64. Hadley C, Lindstrom D, Tessema F et al. (2008) Gender bias in the food insecurity experience of Ethiopian adolescents. Soc Sci Med 66, 427-438.

65. Borooah VK (2001) Logit and Probit: Ordered and Multinomial Models. Sage University Papers Series on Quantitative Applications in the Social Sciences. Thousand Oaks, CA: SAGE Publications, Inc. 